国際教育協力の現状と課題

\title{
ラテンアメリカにおける国際教育協力の 現状と課題
}

江原 裕美

(帝京大学)

\section{はじめに}

1980年代から90年代にかけてのラテンアメリカでは、教育を取り巻く状況が大 きく変化した。1980年代の累積債務危機の混乱、軍事独裁政権の撤退、民主化を 経て、各国はいわゆる新自由主義的な政策に転換した。国際的には、冷戦の終結、 中米和平の進展 $(1987 〜 1996)$ 、北米自由貿易協定 (NAFTA、1994〜) を始めとす る地域経済統合の動きの活発化など、市場を中心としたグローバル化時代が到来 したといわれ、その対応が急がれている。

各国はその中で、1) 経済成長に有利な、技能を有した柔軟な労働力の供給、2) 社会統合と民主主義の促進、3) 社会的不公正と貧困の緩和 ${ }^{(1)}$ を教育の目的とする ことになると考えられている。ラテンアメリカでは1980年代から教育改勒開始 されていたが、ジョムティエン会議を契機として、多くの国でナショナル・プラ ンに基づき教育機会の拡大や修了率の向上の努力に加え、制度改革を進めた。そ こでは教育制度の再編、地方分権化の促進、カリキュラムの再編成、学業成績へ の注目と評価の重視、などを強調する新たな教育戦略が採用されている ${ }^{(2)}$ 。

しかし、同地域では貧困や政治の不安定、価値観の変化など、社会の様々な問 題が深刻化している。1980年から1997年にかけて、初等教育の総就学率が 104.1\%から $113.6 \%$ 、中等教育では44.4\%から62.2\%へと拡大した ${ }^{(3)}$ という数 字は出ているものの、未就学の存在、初等教育での留年や中途退学の多さ、修了 率の低さなどの慢性的問題が解決されておらず、新自由主義がもたらす社会変化 の中で教育の役割を再構築する必要が生じているように思われる。

ラテンアメリカではどのような国際協力が展開され、何が課題となっているの 
だろうか。本稿では、ラテンアメリカにおける国際機関や二国間機関の教育協力 を中心にその動向を報告する。

\section{1. ラテンアメリカにおける教育協力の枠組み——地域協力—}

長い植民地時代を経て独立したラテンアメリカ諸国では、古くからキリスト教 のミッションや民間の交流、また外交政策などを通じて欧米諸国による教育面の 援助や交流の歴史がある。今日では地域協力として受け継がれ、それがこの地域 の特徴となっている。

この地域での本格的な国際教育協力は、1961 年、ケネディ大統領によって表明 された「進歩のための同盟」計画を喵矢としている。同時期、ユネスコの三つの地 域会議 ${ }^{(4)}$ は教育開発に向けての優先課題と方向性を示した。ラテンアメリカの教 育課題を取り上げたサンチアゴ会議では、経済社会開発と関係させた教育拡大お よび、1970年までに 6 年間の初等教育の普遍化という目標を掲げた。教育協力に ついてもその拡大と調整の必要性を提起している ${ }^{(5)}$ 。

その後もユネスコや他の地域組織、国際機関による努力があり、特に1980年代 から 1990 年代にかけ、地域を単位とした教育普及運動が複数現れている。「万人 のための教育 (Education For All)」も世界的な教育推進運動であるが、それ以外に、 ラテンアメリカでは主要なものとして三つを挙げることができる。

代表的なものはユネスコの「基幹教育プロジェクト (Proyecto Principal de Educación, PPE)」と呼ばれるもので、1979年に教育大臣と経済計画大臣が集合し たメキシコ会議以来、2000年までの 20 年にわたり、ラテンアメリカ・カリブ海地 域38力国が、教育大臣会議や政府間委員会を結成して定期的に集合し、教育の改 善に向けた提言を行ってきた ${ }^{(6)}$ 。

南北アメリカにわたるのは、「アメリカス・サミット行動計画（Summit of the Americas Plan to Action)」で、1994年アメリカ合衆国の提唱によりマイアミで開か れた第 1 回アメリカス・サミットで合意され、第16項目が教育を扱っている。 キューバを除き、合衆国、カナダを含む 34 カ国が加わっている ${ }^{(7)}$ 。

また1940年代末に起源を持つ「教育科学文化イベリア諸国機構 (Organización de Estados Iberoamericanos para la Educación, la Ciencia y la Cultura)」は、キューバを含 むイベロアメリカ諸国とスペイン、ポルトガルの 23 カ国が加入しているが、1991 
表 1 ラテンアメリカ地域協力一教育関連

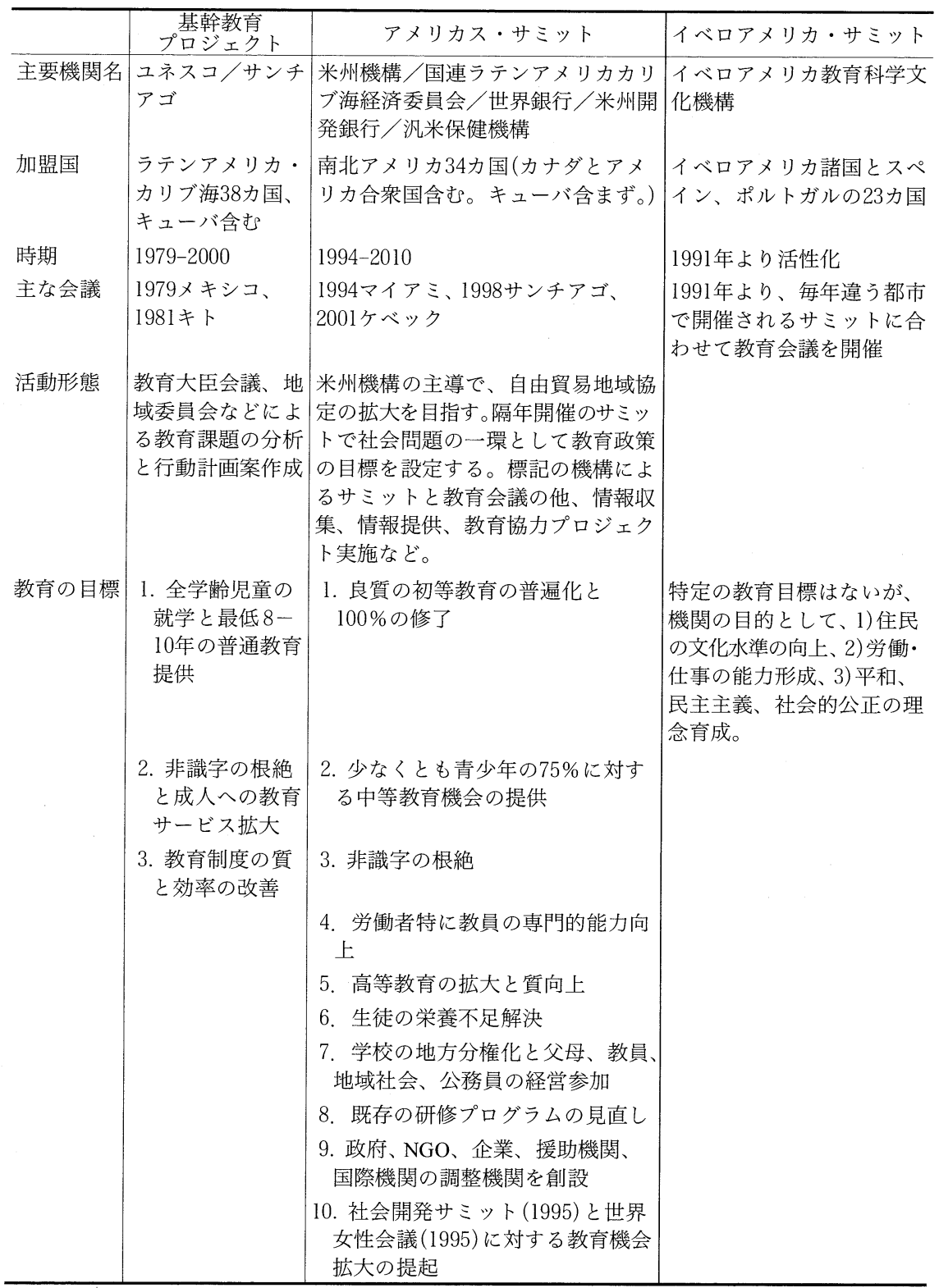

出所)Rosa María Torres,""Cooperación Internacional" en educación en América Latina: Parte de la solución o parte del problema?," en Cuadernos de Pedagogia, No.308, Barcelona, Dic. 2001, p.12 に一部加筆。 
年に始まった第 1 回イベロアメリカ・サミットを機にイベロアメリカ諸国教育会 議を定期的に開催し、特定の目的や活動分野は定めず、様々な教育の課題に取り 組んでいる ${ }^{(8)}$ 。

これらは、地域または共通する文化を基に連合を作り、会議に参集して情報交 流を行い、相互の政策形成に資することを目的としている。それぞれの間に特に 関係はなく別個の取り組みであるが、設定される目標には共通点も多い（表 1 参 照)。そこに国際機関や二国間援助機関が外交的な経緯から色々な形で関係して いる場合も多く ${ }^{(9)}$ 、各国の教育政策に、直接間接の影響を与えている。

\section{3. ラテンアメリカにおける教育整備活動の傾向——国際機関・援助機関}

上記のような地域協力が地域の教育目標や優先政策の発表を中心としているの に対し、国際機関、二国間援助機関はそうした活動と同時に投資や技術協力を通 じて実際に教育整備を行う点に特色がある。1990年以降、ラテンアメリカでは教 育に対してかつてないほど多額の投資が行われているが、その最大の融資元は世 界銀行、続いて米州開発銀行であり、両者は融資と同時に様々な助言や技術協力 を行っている。以下では両機関と、歴史上地域と関わりの深いUSAID、および 日本による教育協力の動向を概観する。

\section{（1）世界銀行}

1990年から2004年にかけて世界銀行による対ラテンアメリカ教育融資の総額は 74億8,350万ドルで、1963年以降1989年までの総額 13 億5, 600万ドルの 5 倍以上と なっている。また、ラテンアメリカは、当該時期の世界銀行による全教育融資の $30.2 \%$ 占め、続く東アジア・太平洋地域の $19.6 \%$ をかな上回り、最大の資金 投下先であった ${ }^{(10)}$ 。また表 2 のサブセクター別合計に見られるように、その うちの 3 分の 1 が初等教育に、 5 分の 1 弱が高等教育に向けられている ${ }^{(11)}$ 。

世界銀行は特に教育を貧困削減のための優先政策と位置づけて、1）「万人のた めの教育」の実現、特に2015 年までに全ての少年少女が良質な初等教育を受けら れるようにする、2) 世界的な知識主導型市場 (knowledge-driven market) で競争す る力をつける、という二つの目標を各国が実現できるよう支援すると述べる(12)。 今後世界は、肉体的能力ょりもアイデアに、原材料の加工や集約的労働よりもテ 
表 2 ラテンアメリカにおける世界銀行の教育投資：サブセクター別推移１990-2004

(金額の単位：百万ドル)

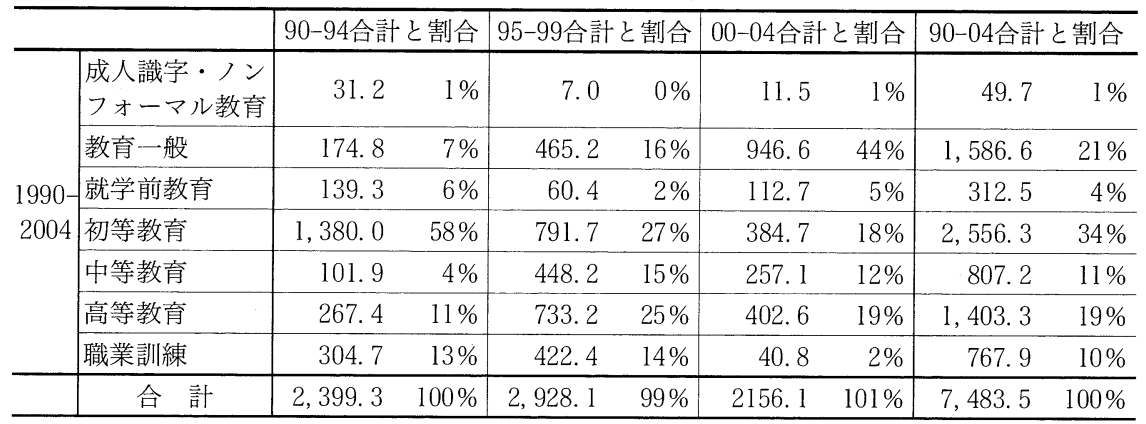

注)四捨五入のため\%の合計は100でないことがある。

出所) http://devdata.worldbanl.org/edstats/worldbanklending/file2005/file\%203a.xls より作成。

クノロジーの応用に基盤を置く「知識経済 (knowledge-based economy)」に向かい、 教育は知識を活用する人材育成の面で知識経済に貢献するとされる ${ }^{(13)}$ 。

しかしラテンアメリカは初等教育の修了率がまだ低く、中等教育の普及度も高 くない段階にある。そこで世界銀行は、ラテンアメリカの教育課題として、1）世 界他地域の労働者との学歴格差の拡大、2）地域間・民族間・経済社会階層間 · ジェンダー間などによる就学率格差に見る不公正、3) 学業成績の不振、4) 社会的 ニーズに即さない教育内容、5) 財政も含めた制度運営上の問題、6) 未熟なテクノ ロジー利用を挙げ、その解決のために、1)排除されてきた人々を組み入れるため、 対象の絞り込みや、教育以外のベーシック・ニーズの配慮、幼児期からの介入、 2) 学習方法の改善や教師の資質向上、学習成果の評価などを通じた教授・学習過 程の変革、3）特に中等教育における青少年のニーズへの配慮、4) 中央や地方の教 育行政の改革、5) テクノロジーの活用、6) 高等教育の改革、など多岐にわたる提 案をしている(14)。

表 2 から、まず目を引くのは、職業訓練が激減し、教育一般が割合を増してい ること、初等教育への配分額が下がってきていることである。教育一般の約半分 は初等教育が占めると原資料に記されているが、それを含めても減少している。 また、就学前教育と成人識字教育への配分額は一貫して低い水準にある。初等教 育が、実質額、割合とも減らす一方で、中等、高等教育は90年代前半の 2 倍程度 の水準を占めるに至っている。今後の傾向がどうなるのか、「排除された人々の 
統合」に有効であるか、今しばらく見極める時間が必要だろう。

\section{(2) 米州開発銀行}

ラテンアメリカで世界銀行と肩を並べる存在感を持つ米州開発銀行でも教育へ の融資は急増している。1990年から 2004 年までの総額は 40 億 9,260 万ドルで、こ れは1962年から1989年までの教育への全投資総額12億370万ドルのほぼ3.4倍であ る。90年以降 5 年毎の合計を見ると 1990-94年、95-99年もともに 13 億ドル台、 2000-04が14億ドル台へと漸増している ${ }^{(15)}$ 。

米州開発銀行は加盟国の開発戦略の中に教育活動を統合することを目指し、教 育協力の目的として、1) 開発に必要な人的資源の養成 (経済社会開発の振興・運 営に必要な科学技術的知識や技能の形成）、2）教育機会の均等（そのため国家の 「公正」な条件作りの支援)、3) 教育投資の効率性確保 (合理的な教育計画策定と根 本的改革の支援 ${ }^{(16)}$ を挙げている。活動の優先分野としては、高等教育、専門技 術教育、成人や青少年に対する社会的ないし労衝上必要な技能の付与、初中等教 育の制度・運営・カリキュラム・教授方法などの改革、資金運用における効率性 と公正さを高める活動、という五つを挙げており ${ }^{(17)}$ 、重点は主に中等後の教育 にある。初中等教育に関しては、就学機会の増加よりも、質や公正さの改善に支 援をしてきた。しかし2000年の戦略指針では、特に中等教育への就学機会拡大に 協力する方向を打ち出している ${ }^{(18)}$ 。

上記指針にあるように米州開発銀行では、長期的な経済成長における人的資源 の重要性を前提とした教育課題の認識は、世界銀行のそれと大きな違いはない。 しかし、「知識経済」「生涯教育」といったタームでグローバルな分析を展開し、教 育の目標を提示する性質は世界銀行ほど強くはない。むしろ、現状をふまえて中 等教育の就学機会増大を打ち出すとともに、教育改革の権限は各国にあるとして、 それぞれの国内的制度やニーズ、時機、また地方の経済的教育的条件を考慮する と述べる(19)など、地域的観点を持つという特徵がある。

\section{（3） USAID の教育協力}

このほかに、ラテンアメリカで教育に関わる主な機関の一つとして USAID が ある。ラテンアメリカに対する $1990-2001$ 年の教育への投資額合計が 6 億 8,087 


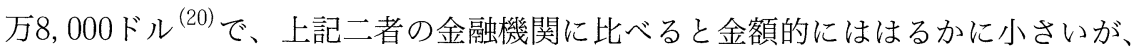
いくつかの国では存在感を発揮している。

USAID については教育協力に対する理念や実践の点で世界銀行に非常に近い と指摘されているが(21)、二国間援助機関として、アメリカ合衆国の外交戦略の 一環であることが明確に打ち出されているという特徵を持っている。上記の期間 における教育協力の累計金額を国別に眺めると、金額の多い順にエルサルバドル 1 億 2, 017 万ドル、次いでグアテマラ 7, 268 万ドル、ニカラグア 6, 274万ドル、ハ イチ 5,248 万ドル、ホンジュラス 3,704 万ドル、となっており、全て中米紛争の当 事国や地理的に近く政情が直接関係する国々である。これらの国々への援助は規 模や継続性の点で他国と比べ際だっており、合衆国の外交戦略における重要性を 反映している(22)。

合衆国にとって、ラテンアメリカにおける、独裁体制から民主主義的体制への 移行と安定の達成、麻薬問題の解決、債務削減と経済成長の実現、自由貿易協定 の締結、各国内の健康や教育の極端な不平等や HIV/AIDS の問題解決などは、合 衆国の安全や繁栄に対する脅威を減じることとなるのであり、「民主主義、安全 保障、市場重視の経済開発」を進めることが、USAID の国際協力の戦略となる。 これに基づき、主要なプログラムは、1）良いガバナンスと民主主義の実現、2)自 由貿易協定の拡大による経済成長の達成、3) 人々への投資、4) 麻薬生産に頼らな い経済開発、5) 民間セクターの力を利用した経済開発、6) USAID 自身の効率性や 有効性の向上に分けられている。教育はこのプログラムの一環として、言語・数 学・科学の面で教育の質を向上させ基本的学力を身につけた生徒を送り出すこと を目指し ${ }^{(23)} 、$ 多様なプロジェクトを実施している。

\section{（4）日本の教育協力}

日本は、複数のラテンアメリカ諸国において、開発協力へのトップドナー、も しくは出資が最も多い国の一つとなっている。例えばブラジルに対しての ODA 拠出額は2001年から2002年にかけての平均が 1 億7, 100万ドルで2位の EC7, 600万 ドルを大きく引き離している(24)。ただし教育協力に関しては、件数はごく少な く、主として中米地域において、内戦終結後の開発協力の一環として基礎教育へ の支援を行ってきた。 
代表的な例として、まず JICA（国際協力機構）によるグアテマラの先住民女子 への初等教育支援が挙げられる。日米の「援助協調」の一環として始まったが、日 本の独自の取り組みによってさらに発展した。1996年 2 月から 1999年にかけ、教 材使用状況や教育方法を把握のうえ、教員研修、小学校建設、教育行政官の研修、 女子教育セミナーの開催、女子教育計画作成、などを含む総合的な女子教育整備 の事業であった ${ }^{(25)}$ 。また、同じくJICA のホンジュラスに打ける算数科指導力向 上プロジェクトは、2002年までに 13 年間にわたり青年海外協力隊 58 名が述べ 2 万 人に教員研修を行ってきた実績が評価され、大学における現職教員研修プログラ ムの全国展開を図るもので現在実施途上である ${ }^{(26)}$ 。

2002 年度の JICA の事業予算の中で、北米と中南米の合計シェアは、17.3\%に 留まるが(27)、上記のような2 例は、それまでの日本の実践を取り入れた教育協 カプロジェクトが生まれつつあることを示している。ほかに1999年から米州開発 銀行の中に、日本政府が出資して「ジャパン・プログラム」が設置され、アジアと ラテンアメリカの経験の交流や、ラテンアメリカの社会経済開発への寄与を目的 とする研究や研修コースなどを行っている(28)。

\section{3. 教育協力の実例から}

\section{（1）プロジェクトの増加と範囲の拡大}

上記の諸機関は、一国内で具体的にどのような活動を行っているのだろうか。 ブラジルを例に取ると、世界銀行は1997年以降、基礎教育プロジェクトを 5 件 と科学技術振興プロジェクトを 1 件承認している ${ }^{(29)}$ 。米州開発銀行は2004年 9 月 までにいずれも中等教育段階以降の 8 件の教育協力プロジェクトを承認した ${ }^{(30)}$ 。 USAID は危機的状況にある青少年の再雇用を目指す教育訓練プログラムを 1 件 行っている ${ }^{(31)}$ 。

ラテンアメリカ全体の傾向と同様、ブラジルにおける教育協力は金額的にも増 加している。世界銀行を例に取ると、1997年から2004年10月の間では 7 億ドル近 くになっているが、1987年から 1990年にかけての期間を振り返ると教育分野の融 資は 7,400 万ドル、ブラジルに対する融資全体の中で $2 \%$ を占めるに過ぎなかっ た。それが、1991年から1994年においては 1 億5, 900万ドルへと急増し、この時期 対ブラジル融資に占める割合でも $29 \%$ にまで上昇した ${ }^{(32)}$ 。 
表 3 主要機関の国際教育協力

\begin{tabular}{|c|c|c|c|}
\hline & 世界銀行 & 米州開発銀行 & USAID \\
\hline $\begin{array}{l}\text { ラテンアメリカ } \\
\text { 地域への投資額 }\end{array}$ & 74億8, 350万ドル (1990-2004) & $\begin{array}{l}\text { 40億9, 260万ドル (1990- } \\
\text { 2004) }\end{array}$ & $\begin{array}{l}6 \text { 億 } 8,087 \text { 万 } 8,000 \\
\text { ドル }(1990-2001)\end{array}$ \\
\hline 目 的 & $\begin{array}{l}\text { 教育は貧困削減のための優先政 } \\
\text { 策。 } \\
\text { 1.「万人のための教育」の実現、特に2015年までに全ての少年 } \\
\text { 少女が良質な初等教育を受け } \\
\text { られるょうにする。 } \\
\text { ら. 世界的な知識主導型市場 } \\
\text { (knowledge-driven market)で } \\
\text { 競争する力をつける。 }\end{array}$ & $\begin{array}{l}\text { 1. 開発に必要な人的資源 } \\
\text { の養成 } \\
\text { 2. 教育機会の均等 } \\
\text { 3. 教育投資の効率性確保 }\end{array}$ & $\begin{array}{l}\text { 良質な教育機会の } \\
\text { 世界的普及、特に } \\
\text { イスラム圏に焦点 } \\
\text { を置く。ミレニア } \\
\text { ム開発目標の } 2015 \\
\text { 年までの目標達成。 }\end{array}$ \\
\hline $\begin{array}{l}\text { 主たる活動分野 } \\
\text { または特色 }\end{array}$ & $\begin{array}{l}\text { 幼児教育から高度な技能養成ま } \\
\text { で各国の全てのニーズに応える } \\
\text { ホーリスティックな性質／長期 } \\
\text { の持続性／教育の質と学習成果 } \\
\text { を重視する教育制度作り }\end{array}$ & $\begin{array}{l}\text { 高等教育、専門技術教育、 } \\
\text { 成人青少年に対する社会的 } \\
\text { 労働的技能の付与、初中等 } \\
\text { 教育の制度・運営・カリ ・カ } \\
\text { キュラム・教授方法などの } \\
\text { 改革、資金運用における効 } \\
\text { 率性と公正さを高める活動 }\end{array}$ & $\begin{array}{l}\text { 1. 良質な基礎教 } \\
\text { 育機会の均等 } \\
\text { (特に女子教育) } \\
\text { 2. ダカール・ } \\
\text { フォーラムやミ } \\
\text { レニアム開発目 } \\
\text { 標にある世界の } \\
\text { 教育目標を実行 }\end{array}$ \\
\hline $\begin{array}{l}\text { ラテンアメリカ } \\
\text { における優先的 } \\
\text { 教育課題 }\end{array}$ & $\begin{array}{l}\text { 排除された人々の統合、教授活 } \\
\text { 動の質の向上、学校から社会生 } \\
\text { 活へのムーズな移行、地方分 } \\
\text { 権化の推進、高等教育の多様化 } \\
\text { と改革、教育革新(特にテクノ } \\
\text { ロジー)の推進と研究 }\end{array}$ & $\begin{array}{l}\text { 中等教育、教師教育、教科 } \\
\text { 書教材の供給、テクノロ } \\
\text { ジーの選択的使用、地方分 } \\
\text { 権化、幼児教育 }\end{array}$ & $\begin{array}{l}\text { 初中等教育の質と } \\
\text { 有効性、教師教育、 } \\
\text { 教育改革、雇用の } \\
\text { ための訓練 }\end{array}$ \\
\hline $\begin{array}{l}\text { 教育プロジェク } \\
\text { トの例 (ブラジ } \\
\text { ル) }\end{array}$ & $\begin{array}{l}\text { 北東部の初等教育の普及と質向 } \\
\text { 上/科学技術振興 }\end{array}$ & 中等教育、職業技術教育 & $\begin{array}{l}\text { 危機に立つ青少年 } \\
\text { の雇用訓練 }\end{array}$ \\
\hline
\end{tabular}

出所) http://www1.worldbank.org/education/topicbrief/asp, http://www.iadb.org/exr/pic/VII/OP_743.cfm?langua ge=english, http://www.iadb.org/sds/doc/EDU\%2D113E.pdf, http://www. usaid.gov/policy/budget/cbj2005/ lac/, http://www.usaid.gov/policy/budget/state_usaid_strat_plan.pdf から筆者作成。

融資の対象も連邦政府だけでなく州政府も含まれるようになったほか、セク ター全体への政策アドバイスを含めた複合的なアプローチが採用されてきた。そ れは次第に一つのセクターや狭い区域を超え、広い地域全体に対して分野横断的 に総合的に開発を進める方向を目指すようになっている。ブラジルでは北東部が 第一の優先対象となり、上記の教育プロジェクトの大部分もこの地域を対象とし ている。 


\section{（2）学校運営改革への志向}

教育協力はその目標がアクセスの増加に留まらず、学校自体の改革を目指す複 雑なものになりつつある。その一例として、未就学者の割合を減らすのに貢献した とされるブラジルの「学校強化基金プロジェクト (Projeto Fundo de Fortalecimento Escolar 通称 FUNDESCOLA) 」がある ${ }^{(33)}$ 。プロジェクトに関係するブラジル人経 済学者からは、ブラジル側の考えが取り入れられ、世界銀行の姿勢の変化とブラ ジル側の人材の成長を示すものという見解もあるが ${ }^{(34)}$ 、概要は以下のようであ る。

ブラジルの初等教育の重要問題の一つが地域差である。ブラジルでは大きく分 けて南と北で所得の格差が大きい。州ないし市(自治体)が初等学校を運営してい るため、貧しい地域では学校に支出される公的経費も非常に少なかった。1998年 以来、生徒 1 人あたりに同額の公的最低支出を義務づけるシステム ${ }^{(35)}$ が作られ 変わってきたが、今なお、学校の施設設備や教師の資格などで南と北の条件の差 は大きい。生徒が留年、中途退学する率も高く、標準年齢を超える生徒が多数在 籍している ${ }^{(36)}$ 。FUNDESCOLA は北部、北東部、中西部の19州における初等学校 の改善を図る中期的な総合的プロジェクトで、建物設備が貧弱な学校に「最低運 営基準（Minimum Operational Standard）」を満たすよう物理的支援をし、学校改革 の方法と予算を提示して努力を促すことで、進級率と卒業率を高め学力水準を引 き上げることが目的である。

第一期は1998年から2000年にかけて行われたもので、四つの構成部分からでき ている。第一は学校の「最低運営基準」を設定し、黒板や机、椅子などベーシック な設備を付与する。また各学校の補修・改善計画に予算措置を行う。第二は学校 の合理的、民主的運営のため「学校発展計画 (School Development Plan)」を各学校 が策定し、これに予算もつけるものである。第三は合理的な学校建設計画と建築 モデルの提示である。標準的な学校建設モデルを提示して、各自治体で合理的な 学校建設や教室増設ができるよう指導する。第四は学校運営とプロジェクト管理 の能力強化と共に、教員研修による教授能力の向上、地域社会の参加を促進し、 国の情報システムの充実を図る ${ }^{(37)}$ 。

プロジェクトの実施単位として、国勢調査の基礎単位となっている「マイクロ リージョン (microregions)」を採用した点に特徴がある。これにより、州と自治体 
を始め他の関係機関との連絡と調整が容易となった。第一期は、北部と中西部の 10 の州都のマイクロリージョンにおいて各学校から 3 人が 4 日間のコースである 「学校発展計画」の研修 ${ }^{(38)}$ を受けて学校改善の手法を学んだ。学校の基本的デー タの取り方を学び、チェックシートを用いて学校の機能を分析し、改革的見地 から学校の評価を行う ${ }^{(39)}$ 。マイクロリージョンへの融資と指導は初年度 FUNDESCOLA の全額負担であるが、年度を追うごとにその負担を減らし、最終的に は各州や市が自ら学校改善を続けていけるよう意図されている ${ }^{(40)}$ 。

第二期は、「最低運営基準」や「学校発展計画」の普及、FUNDESCOLA プログラ ムの広報、情報システムの整備、教育制度の運営改善という第一期とほぼ同様の 構成のプロジェクトが、北東部の 9 つの州都にあるマイクロリージョンと、北部 中西部の 18 のマイクロリージョンとに拡大された ${ }^{(41)}$ 。第三期は 2002 年に承認さ れ現在も継続中であるが、第一期二期を引き継ぎ、「最低運営基準」の普及の他、 学校発展計画の一環として、新しい教授・学習モデルの実行、学校評議会の設置 を組み込み、州や自治体の教育局など教育行政の強化も図っている ${ }^{(42)}$ 。

\section{おわりに}

ラテンアメリカでは、緊密な地域協力を背景に教育協力の規模が急激に拡大し、 同時にその重点分野や活動形態、方法も様々な変化を遂げて多様化してきた。し かしそのあり方と各国の政府や市民社会との関係は単純なものではなく、それが 教育に反映するプロセスはまだ充分探究がなされているとはいえない。

FUNDESCOLA の柱の一つは学校運営のシステマチックな改善であった。しか し、縁故主義が強く、透明性の確保が課題であるブラジルの土畩において、学校 内部の「合理的」な改革アプローチがすぐに成果を上げるのは難しいと思われる。

世界銀行のレポートは、FUNDESCOLAＩ抢よびIIの「学校発展計画」による生 徒の学習成績や進級率に対するプラス効果を示唆する一方 ${ }^{(43)}$ 、行政の指導や学 校運営の改善が、教室内の教育活動を直ちに変えるかどうかは未だ実証されてい ないことを認め、授業中の実質的学習活動の増加、基礎的スキルの定着練習、保 健指導や給食を含めた早期教育の導入などを提案している ${ }^{(44)}$ 。このことは、プ ロジェクトが就学増や環境整備には一定の効果をもたらすとしても、実質的な教 育活動に対する効果にはなお課題があることを示している。USAID の教育専門家 
ジョン・スワロー（Dr. John Swallow）氏は、ラテンアメリカでは教育制度や学校 運営の改革が試みられ、情報が増加したが、教師の資質を上げること、教室に実 質的な変化を起こすこと、それを教育の質の向上に結びつけていくことはきわめ て難しいと述べている( ${ }^{(45)}$ 。

他方、一般に、教育協力プロジェクト自体が当該国の中に一種の「飛び地」を 作っているというラテンアメリカ教育研究者らの指摘もある。かつてブラジル北 東部でも、地域の実情とかけ離れた学校建設や、建設されても全く機能しないま まの学校の例などが見られたという(46)。プロジェクトの対象となるかどうかで 地域間に大きな差が生まれることもある。当該国の教育に対する国際協力の整合 性が地域の文脈に即して考えられなければならない。

さらに、ラテンアメリカではNGO や住民組織の活動が広がっているが(47)、国 際協力をシステムとして見ると、機関同士のコーディネーションが充分でなく、 重複する課題が複数の機関で取り上げられているために多くの労力と経費の浪費 が生じている。錯綜した機関のあり方が NGO 団体にまで影響して、対立するグ

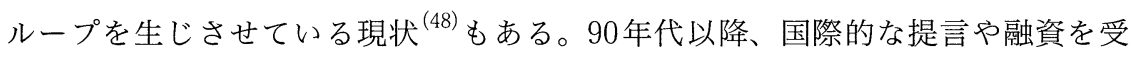
けていないキューバが教育指標で最上位にあるという興味深い事例はよく言及さ れるところである。

インターネット上で 3,000 人の署名を集めた「万人のための教育に対するラテン アメリカの声明 (2000年4月)」 (49)、および「基幹教育プロジェクト」において各国 教育大臣が署名した「コチャバンバ宣言 (2001年 3 月)」 (50) は、教育への関心の高 まりと同時に、そのような背景から生まれている。

教育分野の国際協力は、それぞれの国や社会がどのような発展の道を選ぶのか、 という問題と関わる活動であり、各国の文化の機微に直接触れる難しさを有する ものである。ラテンアメリカでは、軍政を経た歴史的な経緯からも、開発と政治 に対する位置という問題に関連せざるを得ない部分がある。先の二つの宣言が、 協力機関との関係に関して微妙な違いを示しながらも共通して求めているのは、 市民社会と各国政府の教育政策決定における主導権を回復し、各地の固有の状況 への洞察を生かすことであった。新自由主義的な改革が圧倒的な現今の文脈にお いて、教育協力は、グローバル化に即した人材を生み出すだけでなく、人々の生 活・文化と教育のあり方に対する細やかな配慮をもって、激変する社会環境の中 
でも人間としての連帯を育てるものとなりうるかが問われている。社会と人間の 複雑な営みを見つめ、各国の歴史的地域的文脈から教育協力を捉え返す中から、 教育協力研究が一層深化することが望まれる。

今回の論文を書くにあたって、USAID のジョン・スワロー (Dr. John Swallow) 氏、メリーランド大学のスティーブン・クリース (Dr. Steven J. Klees) 氏に有益な 情報と示唆を頂いた。記して感謝したい。

\section{(注)}

(1) World Bank, Educational Change in Latin America and the Caribbean, 1999, p.9.

（2）江原裕美「新自由主義の時代における国家と教育」『国際教育』第10号、2004年。

(3) UNESCO/OREALC, The State of Education in Latin America and the Caribbean, 19802000, UNESCO Santiago, 2001, p.21.

(4) カラチ会議(1959年)、アジスアベバ会議(1961年)、サンチアゴ会議(1962年)。

(5) 教育協力については、国連諸機関、ユネスコ、米州機構や二国間援助機関からの技 術協力と長期貸し付けなど国際金融支援双方の必要性を訴え、各国の総合的開発計画 に教育開発計画作成を組み入れることを提言している。また、この頃すでに国連や他 の米州間機関の間での調整や協力の緊要性という課題を提示している（Ladilav Cerych, Problems of Aid to Education in Developing Countries, Praeger, 1965, pp.17-19)。

(6) UNESCO, Overview of the 20 years of the Major Project of Education in Latin America and the Caribbean, UNESCO-Santiago, 2001.

この報告書の内容は、斉藤泰雄「ラテンアメリカ・カリブ海地域における基礎教育の 開発 20年間の成果と課題」(斉藤泰雄『グローバリゼーション・インパクトと教育改革 に関する研究一メキシコを中心に一』(平成13年度〜15年度科学研究費補助金 基盤研究 (C)(2)研究成果報告書、2004年3 月所収)にも紹介されている。

(7) http://www.summit-americas.org/miamipian.htm (2005年2月9日)

(8) http://www.oei.es/memoria/memo01.htm (2005年2月9日)

(9) 例えば、アメリカス・サミットに関わる米州機構の政策実施には USAID が協力して いる。また、イベロアメリカサミットにはスペインの国際協力機関が運営に関わって いる。

(10) http://devdata.worldbank.org/edstats/worldbank.lending/file2005/file\%202.xls（2005年 4 月 30日)

(11) http://devdata.worldbank.org/edstats/worldbank.lending/file2005/file\%203a.xls(2005 年 4 月 30日）

(12) http://www1.worldbank.org/education/topicbrief.asp(2005年2月12日) 
(13) The World Bank Group, "Chapter 1: The Knowledge Economy and the Changing Needs of the Labor Market," in Lifelong Learning in the Global Knowledge Economy: Challenges for Developing Countries, 2003.

(14) World Bank, Educational Change in Latin America and the Caribbean, 1999.

(15) http://www.iadb.org/aboutus/II/operations.cfm?language=English\# (2005年 5月20日)

(16) http://www.iadb.org/exr/pic/VII/OP_743.cfm?language=english(2005年2月2日)

(17) Ibid.

(18) Inter-American Development Bank, Reforming Primary and Secondary Education in Latin America and the Caribbean: An IDB Strategy, 2000, p.3.

(19) Ibid.

(20) USAID ラテンアメリカ局教育担当ジョン・スワロー(Dr. John Swallow) 氏提供資料よ り(2005年1月 6 日)。

(21) メリーランド大学スティーブン・クリース (Dr. Steven J. Klees) 教授の指摘。

(22) 注(20)に同じ。

(23) http://www.usaid.gov/policy/budget/cbj2005/lac/(2005年2月2日)

(24) Organization for Economic Co-operation and Development Development Assistance Committee, International Development Statistics CD-ROM 2004 Edition, "Geographical Disfribution of Financial Flows to Aid Recipients 1960-2002".

(25) 村田敏雄「日本の政府開発援助（ODA）による教育援助の事例一グアテマラ女子教育 協力一, 斉藤泰雄『開発途上国向けの国際的教育援助プロジェクトの事例的研究一世界 銀行の活動を中心に一』(平成 10 年度 11 年度科学研究費補助金基盤研究(C)(2)研究成果 報告書、2000年)所収。

(26) http://www.jica.go.jp/about/ann2003/pdf/ann2003_10.pdf(2005年5月15日)

(27) http://www.jica.go.jp/about/ann2003/pdf/ann2003_03.pdf(2005年5月15日)

(28) 米州開発銀行「ジャパン・プログラム」2002年 3 月第 4 巻。

(29) 1) ペルナンブコ州総合開発：教育の質向上プロジェクト $(3,150$ 万ドル、2004年 10 月 承認、以下、年月は承認年月)

2) バイーア州教育プロジェクト (6,000万ドル、2003年 6 月)

3) 学校強化基金第三期プロジェクト“FUNDESCOLA III”（1 億6,000万ドル、2002年 6 月）

4)学校強化基金第二期プロジェクト “FUNDESCOLA II” (2 億200万ドル、1999年 6 月)

5) セアラ州基礎教育質向上プロジェクト (9,000万ドル、2000年、12月)

6)第三科学技術改革プロジェクト ( 1 億5, 500万ドル、1997年12月)。

Banco Mundial, O Brasil e o Banco Mundial: Uma parceira que dá certo, Programas e Projetos Julho 2003 および http://www1.worldbank.org/education/projects.asp より。

(30) http://www.iadb.org/exr/doc98/apr/apeduc.htm (2005年4月20日) 
(31) At-Risk Youth Program (2003-2008) と称する。

http://www.usaid.gov/locations/latin_america_caribbean/country/program_profiles/brazilpro file.html および http://www.usaid.gov/policy/budget/cbj2005/lac/pdf/512-010.pdf(ともに2005 年2月9日)

(32) Livia de Tommasi, Mirian Jorge Warde and Sérgio Haddad eds. O Banco Mundial e as políticas educacionais, Cortez Editora/Ação Educativa/PUC-SP, 1998, pp.34-35.

(33) http://www-wds.worldbank.org/servlet/WDSContentServer/WDSP/IB/1998/03/16/0000092

65_3980429110831/Rendered/PDF/multi0page.pdf(2005年2月16日)

(34) アントニオ・シャビエル (Antônio C. de R. Xavier) 氏 (応用経済研究所)より (2003年 9 月 9 日)。これは必ずしも一般的な見方というわけではなく、教育学者に関しては世 界銀行に関して批判的な見方が多い。

(35) 1996年に制定された「初等教育維持発展および教職向上のための基金（Fundo de Manutenção e Desenvolvimento do Ensino Fundamental e de Valorização de Magistério)」。 (36) 2000 年ブラジル全国で、初等学校 I 年生が 2 年生に進級した割合は $62.8 \%$ 、全学年通 してみても 73.4\%であり、4.9\%が退学している。標準年齢外の生徒の割合は $41.7 \%$ で あった。江原裕美「1990年代ブラジルの初等教育改革」『帝京大学外国語外国文学論集』 第10号、2004年、pp.68-71.

(37) World Bank, "Project Appraisal Document on a Proposed Loan in the Amount of US\$62.5Million to the Federative Republic of Brazil for School Improvement Project-FUNDESCOLA I," March 16, 1998, p.9. At http://www-wds.worldbank.org/servlet/WDSContent Server/WDSP/IB/1998/03/16/0000092653980429110831/Rendered/PDF/multi0page.pdf (2005 年 2 月 15 日)

(38) FUNDESCOLA, "Capacitação em como elaborar o Plano de Desemvolvimento da Escola," 2003年度教育省配付資料。

(39) FUNDESCOLA, Como elaborar o plano de desenvolvimento da escola, Caderno de Oficinas, Brasilia,2002.

(40) FUNDESCOLA 専門家ジョゼ・アマラウ・ソブリーニョ（José Amaral Sobrinho）氏よ り。(2003年9月10日)

(41) World Bank, "Project Information Document Brazil FUNDESCOLA II Second School Improvement Project," 1998, p.10. At http://www-wds.worldbank.org/servlet/WDSContentServer/ WDSP/IB/1999/03/19/000094946_99031911063761/Rendered/PDF/multi0page.pdf

(42) World Bank, "Project Information Document Brazil FUNDESCOLA III," 2001, p.6. At http://www-wds.worldbank.org/servlet/WDSContentServer/WDSP/IB/2001/09/29/000094946_ 01092804321243/Rendered/PDF/multi0page.pdf(2005年2月16日)

(43) World Bank, "Project Appraisal Document on a Proposed Loan in the Amount of EUR $182,800,000$ Million (US\$160.0 Million Equivalent) to the Federative Republic of Brasil for 
FUNDESCOLA IIIA (Third School Improvement Project) in Support of the First Phase of the FUNDESCOLA Program," May 17, 2002, p.27. At http://www-wds.worldbank.org/servlet/ WDSContentServer/WDSP/IB/2002/07/02/000094946_02060404024476/Rendered/PDF/multi0 page.pdf(2005年2月16日)

(44) World Bank, "Project Performance Assessment Report Brazil Innovations in Basic Education Project, Second Northeast Basic Education Project, Third Northeast Basic Education Project and School Improvement Project-FUNDESCOLA I," June 20, 2002, pp.18-23. At http://www-wds.worldbank.org/servlet/WDSContentServer/WDSP/IB/2002/08/09/000094946_ 02073104145845/Rendered/PDF/multi0page.pdf(2005年2月16日)

(45) USAID ラテンアメリカ局教育担当ジョン・スワロー氏 (2005年 1 月 6 日)

(46) ロサ・マリア・トーレス (Rosa María Torres)氏(フロネシス研究所、アルゼンチン)に よる。(2005年2月10日)

(47) 江原裕美編『内発的発展と教育一人間主体の社会変革と NGO の地平』新評論、2003年 参照。

(48) Rosa María Torres, "“Cooperación internacional” en educación en América Latina: Parte de la solución o parte del problema?" p.8. At http://www.campus-oei.org/equidad/coopal.pdf (2005年2月 7 日)

要約版が以下に揭載されている。Cuadernos de Pedagogía, No.308, Monográfico “La educación en América Latina," Barcelona, diciembre 2001.

(49) 万人のためのより良い教育を主張する中で、教育政策決定に対する国際機関の役割 の見直し、各国政府と国内社会が教育問題へのイニシアチブを回復することを求め、 知識と各地の固有性をふまえて考え活動するために自らの能力回復を呼びかけている。 http://www.immagen.com/fronesis/rmt/documentosrmt/Pronunciamiento\%20-\%20English.pdf (2005年2月13日)

(50) 各国の政策決定および実行能力を強化し、アメリカス・サミットのような西半球の イニシアチブを重視すること、協力機関と前進的な関係を維持し、協力の結果を明ら かにすること、各国の関心や特性を尊重すること、各国間の水平的な協力関係を奨励 すること、を謳っている。http://www.unesco.cl/medios/biblioteca/documentos/promedlac_ declaraciones_cochabamba_esp/pdf(2005年2月7日) 